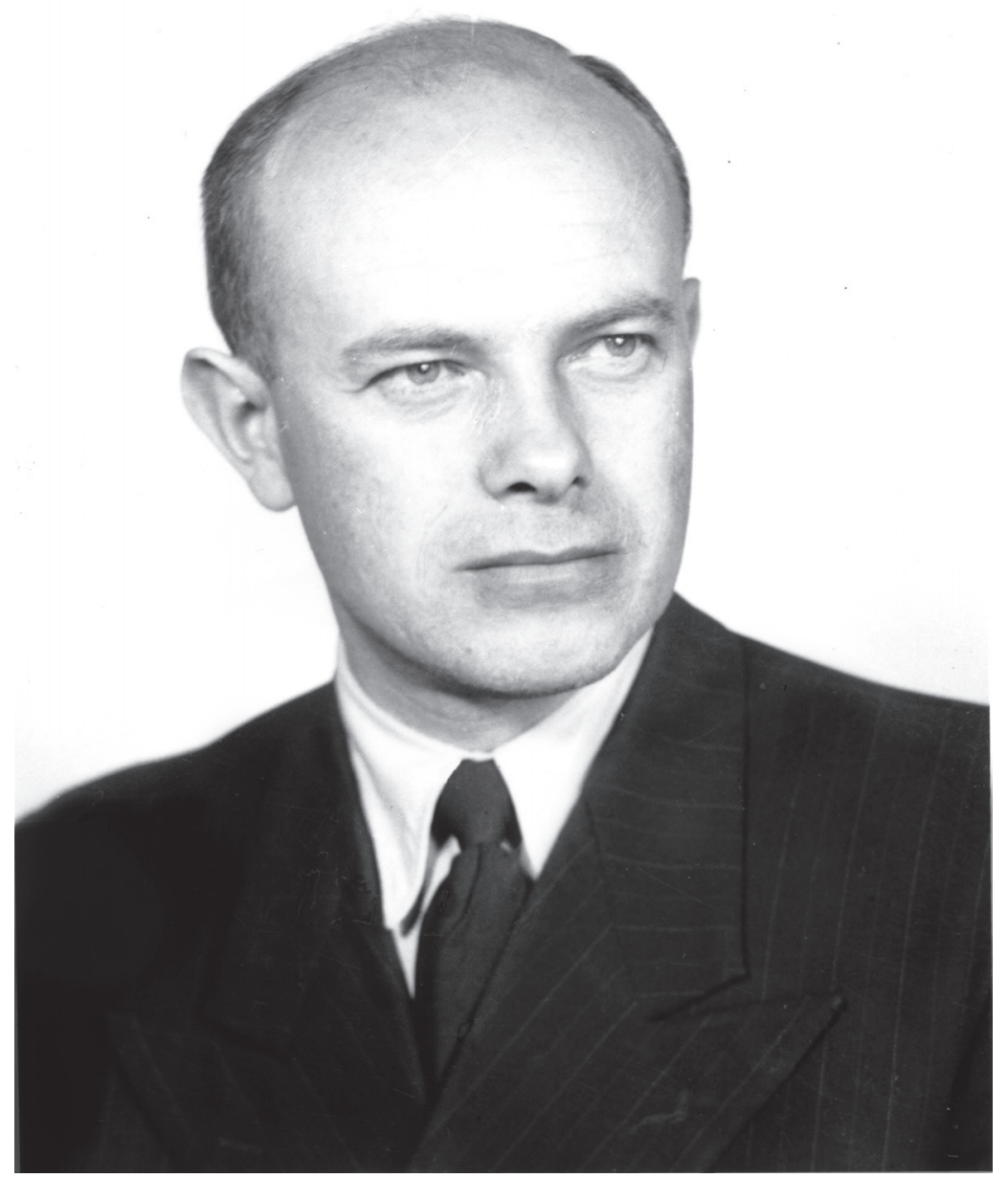

Jan Kowalczyk (23.10.1918 - 25.0I.2007). Photo: Archive of the IAE PAN. 



\section{Docent Dr hab. Jan Kowalczyk (I918-2007)}

\section{Jan Gurba $^{a}$, Hanna Kowalewska-Marszałek ${ }^{b}$, Barbara Sałacińska ${ }^{c}$ and Sławomir Sałaciński ${ }^{d}$}

Jan Kowalczyk was born on October 23, I9I8 in Nowa Wieś in the Lubartów district, Lublin voivodeship. After graduation from the Jan Zamoyski State Gymnasium in Lublin in 1937 and after six months of practice at the Gdańsk Shipyard, he began studies at the Faculty of Ship Machinery Construction at the Gdańsk University of Technology. After the Second World War interrupted his further education, he stood as a volunteer to fight with the German invaders in defence of Lublin in the tragic events of September 1939 (Białasiewicz and Gzella 1994: 130-I31, 208, 2I2). During the German Occupation, he worked physically at the painting workshop in Lublin. After the War, in 1945-1948 he studied at the Faculty of Humanities at the Catholic University of Lublin (KUL). He was a student of Jan Czekanowski (I882-1965), former rector of the Jan Kazimierz University in Lviv and head of the Department of Anthropology of the KUL, of Stefan Nosek (1909-1966), head of the Department of Prehistory of the Maria Curie-Skłodowska University (UMCS), classes at the KUL, and of Józef Gajek (1907-1986), at the same time head of the Departments of Ethnography and Ethnology at the KUL and UMCS.

During his studies, J. Kowalczyk worked in succession as a librarian in the Hieronim Łopaciński Public Library in Lublin - in the period from I0.1944 to 30.06.1945 (Bieleń 2005: 15, 24) and at the Department of Anthropology of the KUL (for part of the academic year 1945/46). From June Ist 1946, he was an employee of the Department of Prehistory (now the Institute of Archaeology) of the UMCS, initially (in the years

${ }^{a}$ Institute of Archaeology, Maria Curie-Skłodowska University, 4 M. C.-Skłodowska Sq., 20-03I Lublin, Poland, ORCID: oooo-0ooI-7473-6326

${ }^{b}$ Institute of Archaeology and Ethnology Polish Academy of Sciences, IO5, al. Solidarności, OO-I40 Warsaw, Poland, e-mail: hanna@iaepan.edu.pl ORCID: 00oo-0002-7356-I402

c State Archaeological Museum in Warsaw, 52, Długa st., 00-24I Warsaw, Poland, e-mail: neolit@pma.pl ORCID: 0000-000I-6I26-397X

${ }^{d}$ State Archaeological Museum in Warsaw, 52, Długa st., 00-24I Warsaw, Poland, e-mail: neolit@pma.pl ORCID: 0000-0002-0767-8979 
Io $\mid$ Jan Gurba, Hanna Kowalewska-Marszatek, Barbara Satacinska, Stawomir Sataciński

1946-1949) as a junior, and then as a senior assistant. From the beginning of his employment, he actively participated in organizing the scientific and didactic base. Professor S. Nosek recollected later, that by the creation of the Department was a lot of merit and disinterested work of the first archaeologist educated in Lublin and the first assistant of the Prehistory Department of the UMCS, MA Jan Kowalczyk. Already in the first months of his work, he was delegated to the Western Territories (the parts of prewar Germany that became part of Poland after World War II) to secure books for the university library and for the Department of Prehistory. Thanks to him, the Library of the Institute of Archaeology is equipped with a rich collection of interwar German literature on archaeology. In 1948, he obtained a master's degree in the field of anthropology, ethnography with ethnology and prehistory at the KUL, based on the work Lubelszczyzna w okresie wptywów rzymskich [Lublin region in the period of Roman influences]. In 195I, he defended his doctoral thesis at the UMCS Obrzadek pogrzebowy $w$ mtodszej epoce kamienia na ziemiach polskich [The funerary rite in the Late Stone Age in the Polish territories], written under the guidance of Professor S. Nosek. The work could not be published, because - according to reviewers' opinions - it did not include references to the dialectical method of historical materialism. In the same year, J. Kowalczyk was dismissed from work due to the liquidation of recruitment for archaeological studies at the UMCS. He returned to the university in 1953.

As an assistant to the Department, J. Kowalczyk had the additional function of the delegate of the State Archaeological Museum (PMA) - as conservator of archaeological monuments of the Lublin and Bialystok voivodships) - and for this reason, among others, he monitored the state of the hillforts and visited the places of accidental discoveries. In 1949 he participated in the first archaeological expedition (by horse-drawn cart!) across the Hrubieszów district.

In the years 195I-1952, he was the organizer and the first post-war head of the Department of Archaeology of the Lublin Museum. He organized the first permanent archaeological exhibitions in Lublin and Zamość. In 1952-1953 he participated in the work of the "Research Commission on the Cherven Cities (or Grods)", taking part in excavations in Gródek on the Bug, in the Hrubieszów district (on a settlement neighbouring the early medieval stronghold of "Wołyń") and in Lipsko Kolonia in the Zamość district.

After Professor S. Nosek left Lublin, J. Kowalczyk was in I953-1954 the head of the Department of Archaeology of Poland at the UMCS. Released from the university "for ideological reasons", from January Ist, I955, he moved to the PMA in Warsaw, where he took the leadership of the Neolithic Department, and in 1971 he became deputy director for scientific affairs.

In 1954-1957, on behalf of PMA, he conducted research - iniciated in 1953 by Konrad Jażdżewski - on a large Neolithic settlement in Gródek, Hrubieszów district, on the Horodysko hill. He published detailed reports on this work (Kowalczyk 1956; 
I957a; 1957c; 1959a [1958]) in the national archaeological journal Wiadomości Archeologiczne. All the material obtained at that time was later submitted to study by Witold Gumiński, a PhD student at the Institute of the History of Material Culture of the Polish Academy of Sciences (Gumiński 1989).

After habilitation in 1969 at the University of Warsaw, based on the work (Kowalczyk 1969b) entitled Poczatki neolitu na ziemiach polskich [The Origins of the Neolithic Age on Polish Territories], in 1972 he moved to the Institute of the History of Material Culture of the Polish Academy of Sciences (IHKM PAN; since 1992 the Institute of Archaeology and Ethnology), where he worked as the head of the Stone Age Department until he retired in 1978. He returned then to the UMCS Department of Archaeology, where he worked in the post of a docent until 1989.

Docent Jan Kowalczyk was one of the best experts on the Neolithic in Poland. He specialized mainly in the issues of Funnel Beaker culture (FBC) and archaeological research conducted especially on the sites of this culture (Stok, Las Stocki, Klementowice in Puławy district, Gródek in Hrubieszów district, Krzemionki Opatowskie in Ostrowiec Świętokrzyski district).

The source material from his research, his findings and hypotheses quickly entered into scientific circulation. A significant part of them is cited in Polish and foreign literature, including in the monumental synthesis Prahistoria ziem polskich [The Prehistory of Polish Lands], vol. I, II, III (edited by W. Hensel in 1975; 1978; 1979) and in volume I of the academic textbook Pradzieje ziem polskich [Prehistory of Polish Lands] (edited by J. Kmieciński in 1989). In a wider circle of readers from I970s he is known as the author of a popular book (Kowalczyk 197Ib) published by the Polish Archaeological and Numismatic Society, entitled Zmierzch epoki kamienia [The Twilight of the Stone Age], which received very good reviews in Polish and Ukrainian journals. He was also quoted in the Ukrainian and Russian language versions of the Archaeology of the Ukrainian SSR (1971; 1975) and in the volume The Eneolithic of the monumental series Archieologija SSSR (Vol. 4: 1992).

Jan Kowalczyk was a deeply religious man. He published his thoughts in the journal Rycerz Niepokalanej [Knight of the Immaculate]. He was characterised by extraordinary modesty and delicacy, winning him the favour of all who were lucky to commune with him.

He was a teacher of many classes of students of archaeology and history at the UMCS - where he lectured in I948-I95I, I953-1955, I960-1963 and 1975-1989. He was awarded by the University with medals "Nauka w Słuzibie Ludu" ["Science in the Service of the People"] in 1974, and "Zasłużony dla Uniwersytetu Marii Curie-Skłodowskiej" ["Meritorious for the Maria Curie-Skłodowska University"] - only the eighth such medal issues until that date (2004); he had also been awarded earlier, in 1970, he was honoured with the medal "Zasłużony dla Archeologii Polskiej" ["Meritorious for Polish Archaeology"]. 
I2 Jan Gurba, Hanna Kowalewska-Marszatek, Barbara Satacińska, Stawomir Sataciński

He received other decorations as well - for professional and social activity in the Polish Archaeological Society he was awarded the Golden Cross of Merit, the Medal of Meritorious Cultural Activist, the Medal of the 2oth anniversary of IHKM PAN, the prize of the Scientific Secretary of the Polish Academy of Sciences (Balcer 1998; Zakościelna 1999; Libera and Gurba 2003: 8-I0; Rozwałka 2003).

He died in Lublin on January 25, 2007. As Professor Andrzej Abramowicz recalled him: he was a man of righteousness, with a discreet sense of humor, a good friend, and an ardent Christian (Abramowicz 20I0: 17).

\section{JAN KOWALCZYK AT THE STATE ARCHAEOLOGICAL MUSEUM IN WARSAW}

Jan Kowalczyk's first contacts with the State Archaeological Museum in Warsaw (PMA) fall in the year 1949, when he took a two-week internship at the Warsaw museum (Zakościelna and Gurba 2007: 384).

In 1954, after being released from the UMCS for ideological reasons, he became involved with the PMA for a longer period (Fig. I). Museum director, Professor Zdzisław Rajewski, who had a very strong position and support in the government spheres of the Polish People's Republic, was not afraid to hire Jan Kowalczyk. He entrusted him with the function of head of the Neolithic Department, and at the end of his Warsaw museum career (in 197I) - the post of deputy director for scientific affairs (Zakościelna and Gurba, 2007: 385).

\section{Publications of Jan Kowalczyk from the Warsaw museum period}

The numerous scientific works by Jan Kowalczyk are well-known in the milieu of researchers on the Neolithic. His achievements can be described as universal. We find both source and synthetic publications in his output. Here we may note just a selection, presented in a chronological order.

One of the first of the publications in this period was a report on graves of the Globular Amphora culture (GAC) from Las Stocki and Stok, Puławy district (Kowalczyk 1953).

In 1956 and 1957 articles devoted to the study of important Neolithic sites were published - settlements and cemeteries of the FBC in Klementowice, Puławy district (Kowalczyk 1957b) and of the FBC settlement in Gródek, Hrubieszów district (Kowalczyk 1956; 1957a; 1957c). Continuation of work in Gródek (Fig. 2), mainly in the area of the so-called "maidan" [square], was discussed in a subsequent article (Kowalczyk 1959a).

In 1956-1957, Jan Kowalczyk discovered inhumation graves with ceramics decorated with cord impressions in the area of this settlement. He described these finds in an article in Wiadomości Archeologiczne, connecting them with the Mierzanowice culture, which was at that time known as the Tomaszów culture (Kowalczyk 1959b). 


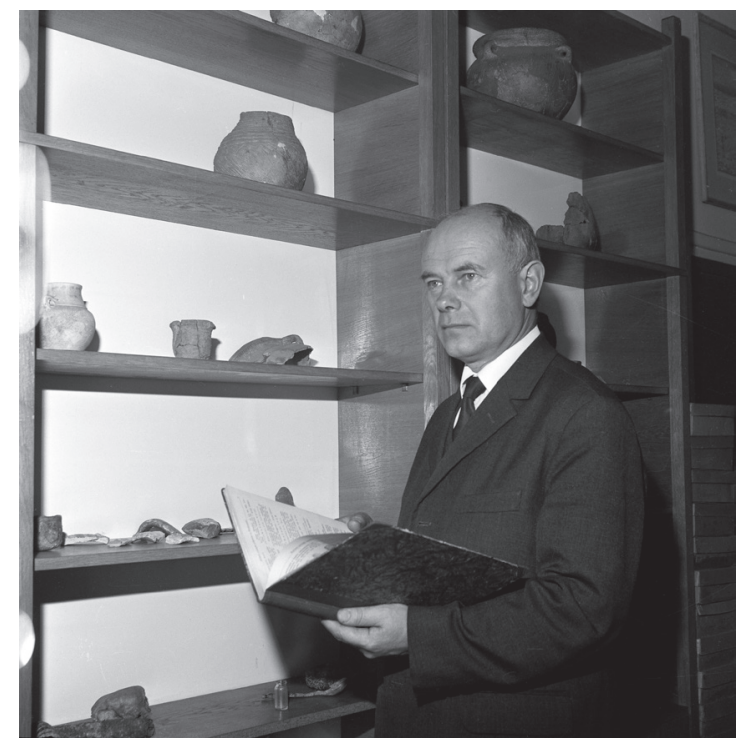

Fig. I. Jan Kowalczyk in his study in the State Archaeological Museum in Warsaw. Photo: T. Biniewski

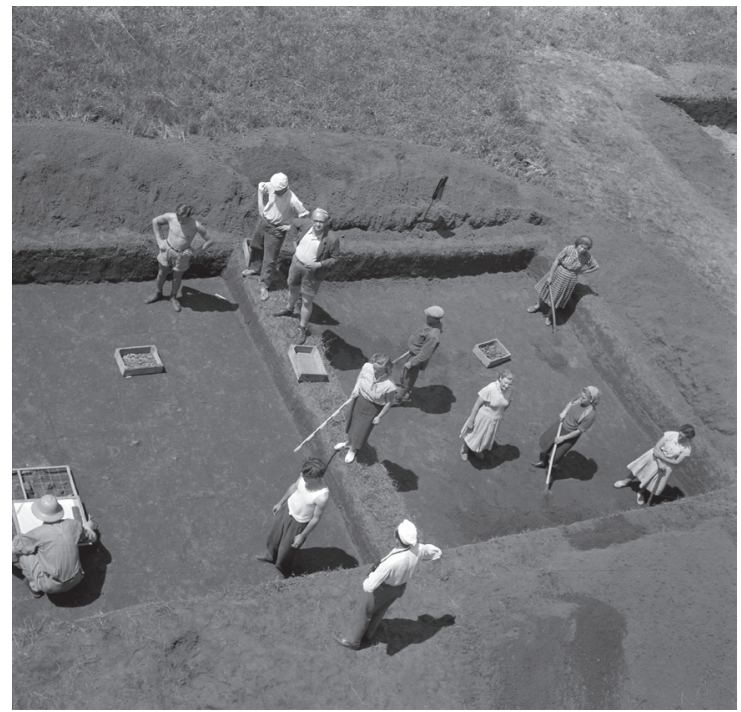

Fig. 2. Jan Kowalczyk during the excavation in Gródek on the Bug [Nadbużny], Hrubieszów district, in 1954. Photo: T. Biniewski 
I4 Jan Gurba, Hanna Kowalewska-Marszatek, Barbara Satacińska, Stawomir Sataciński

In 196I, a paper by Jan Kowalczyk from the symposium in Prague from 1959, concerning the relationship between the FBC and the Tripolye culture (Kowalczyk 196I) was published.

In 1962, Jan Kowalczyk presented his remarks concerning the state of research on the Neolithic of Polish lands (Kowalczyk 1962d); he postulated the necessity for periodic scientific reviews to verify the state of knowledge. In the same year, a very interesting work was published devoted to Neolithic collective graves (Kowalczyk 1962e) and another paper on the importance of test excavations in archaeological research (Kowalczyk 1962c) as well as some kind of summary of the results of the study of the FBC settlement in Gródek, intended for a wider audience (Kowalczyk 1962b).

Jan Kowalczyk did not avoid theoretical discussions, which found expression in the article (Kowalczyk 1963b) Terminologiczne konsekwencje [Terminological consequences]. The author refers to the work of Witold Hensel, devoted to these issues (Hensel 1958). He responds, among other things, to the question of distinguishing prehistory (as a science exploring the oldest history of man), from archaeology (treated here as an auxiliary science of prehistory and history). In the same year, he published an important work (Kowalczyk 1963a) regarding the problems of the Neolithic in Poland in the light of the research results of that time.

Jan Kowalczyk, as an employee of the PMA, did not avoid the problems of archaeological exhibition. He expressed his views in 1964, in the context of the preparation of the exhibition Uwagi o organizowaniu wystaw [The Beginnings of the Polish State], discussing issues related to the organisation of the exhibition (Kowalczyk 1964c).

Three significant articles appeared in 1968. The first of them was about Neolithic complexes from the FBC settlement in Gródek and burial complexes of the GAC from Klementowice that had radiocarbon dates (Kowalczyk 1968a), the second one was on issues related to the Corded Ware culture (Kowalczyk 1968c) and the third discussed cultural transformations in the Neolithic (Kowalczyk 1968b).

One of the fundamental works of Jan Kowalczyk is the publication (Kowalczyk 1969b) Poczattki neolitu na ziemiach polskich [The Origins of the Neolithic Age on Polish Territories], which caused a huge scientific discussion (Kempisty and Gurba 1971; Kozłowski 197I). The author answered his reviewers in a very consistent manner, responding to their comments according to a coherent scheme while discussing the various aspects of the aforementioned work (Kowalczyk 1972).

An equally important publication, The Funnel Beaker culture, which is a synthetic approach to issues related to FBC, appeared as a chapter of the published in English synthesis The Neolithic in Poland (Kowalczyk 1970).

A short but important work by Jan Kowalczyk, devoted to the main problems of the Polish Neolithic, was published in I97I in Sprawozdania Archeologiczne (Kowalczyk I971a). It contained remarks regarding methodological and cultural issues, analyses of the sources and significance of Polish Neolithic in Central Europe. 
The popularization of archaeology in the case of Jan Kowalczyk was not limited to activities in the archaeological reserve area in Krzemionki Opatowskie, Ostrowiec Świętokrzyski district (Fig. 3), and to participation in the organization of exhibitions at the PMA. He wrote, among other things, an article (Kowalczyk 1962a) Nim koto zaczęto stuzyć cztowiekowi [Before the wheel began to serve man]. In the pages of the popular archaeological magazine $Z$ otchtani wieków, among others, appeared his articles: (Kowalczyk 1964a; 1964b) the two-part Lud amfor kulistych [People of the Globular Amphoras], and (Kowalczyk 1969a) Neolit przedceramiczny na ziemiach polskich? [A pre-ceramic Neolithic on Polish lands?]. He was also the author of the popular book (Kowalczyk 1971b) Zmierzch epoki kamienia [The Twilight of the Stone Age]. Combining science with its popular dissemination is, in spite of appearances, a very difficult task. Jan Kowalczyk mastered this skill to a significant degree, bringing it to a high level.

The publications of Jan Kowalczyk from his Warsaw museum period were published in the most prominent periodicals of Polish archaeology in the centres of Warsaw, Łódź and Cracow, such as Wiadomości Archeologiczne, Materiaty Starożytne, Sprawozdania PMA, Archaeologia Polona, Sprawozdania Archeologiczne, Prace i Materiaty Muzeum Archeologicznego i Etnograficznego $w$ Eodzi. The conciseness of these studies, ranging from several to several dozen pages, deserves to be underlined. Despite their compactness, they are written in a very transparent way, and accounts, reports and syntheses do not contain prolix contents and descriptions - they just get to the heart of the matter.

\section{Excavation research}

From the field activity of Jan Kowalczyk in the discussed period, the above-mentioned investigations (1954-1957) of the site $\mathrm{IC}$ in Gródek should be noted, with the remains mainly from the FBC (Fig. 4). These are some of the most important ones, along with excavations of Zofia Podkowińska in the settlement area at the site "Gawroniec" in Ćmielów, Ostrowiec Świętokrzyski district, also related to the FBC. In spite of numerous open-area excavation works from recent years connected with large investments, they are still of paramount importance for research on the Neolithic in Poland and in Europe.

No less important was the research of mine No. 5 in the area of the banded flint mining complex in Krzemionki Opatowskie, Ostrowiec Świętokrzyski district (I9691970), associated with the FBC or GAC - unfortunately its exploration was not completed. After the first season, Zygmunt Krzak withdrew from the research team, having doubts as to the methodology of field work, which, however, from the perspective of the time and experience of the Team for Prehistoric Flint Mining Research of the PMA in Warsaw, should be assessed more positively. Bogdan Balcer, however, was full of research energy. The continuation of this work was difficult for formal reasons: upon the request of Professor Witold Hensel the passage of Jan Kowalczyk to the IHKM 
I6 |Jan Gurba, Hanna Kowalewska-Marszatek, Barbara Satacińska, Stawomir Satacinski

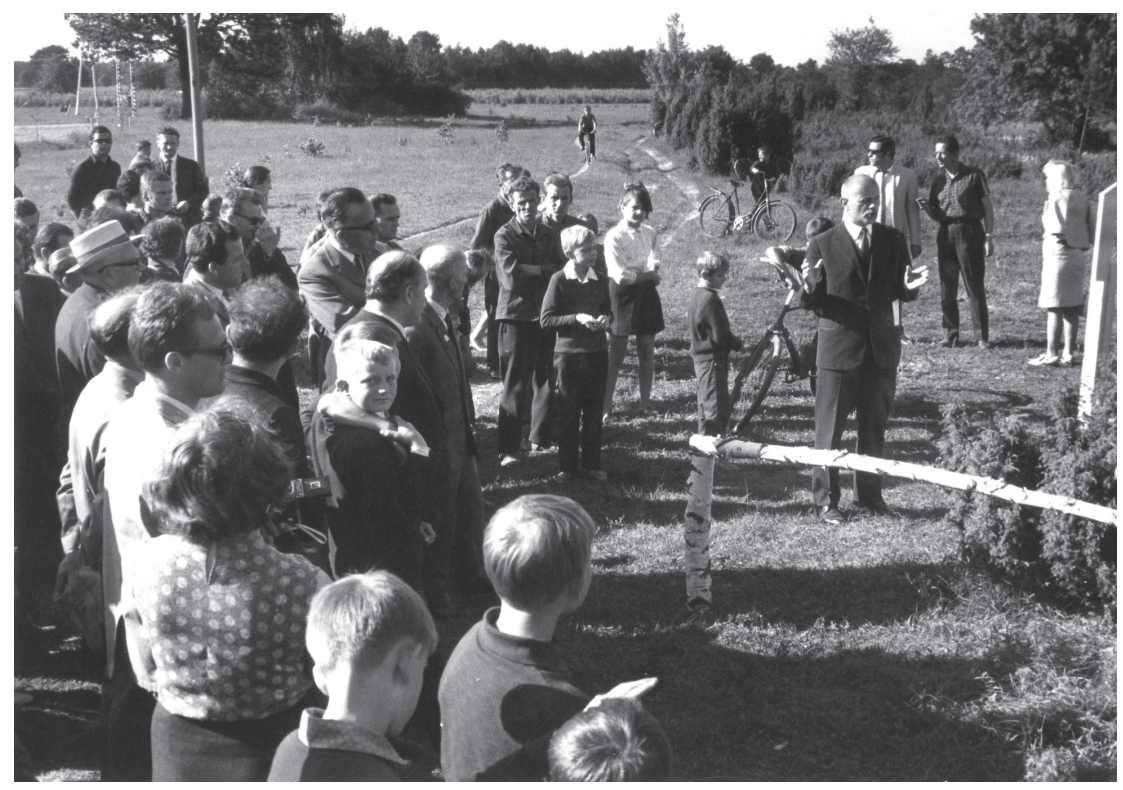

Fig. 3. Jan Kowalczyk's discourse during his excavation in Krzemionki Opatowskie (in 1969 or 1970). Photo: Archive of the State Archaeological Museum, Warsaw.

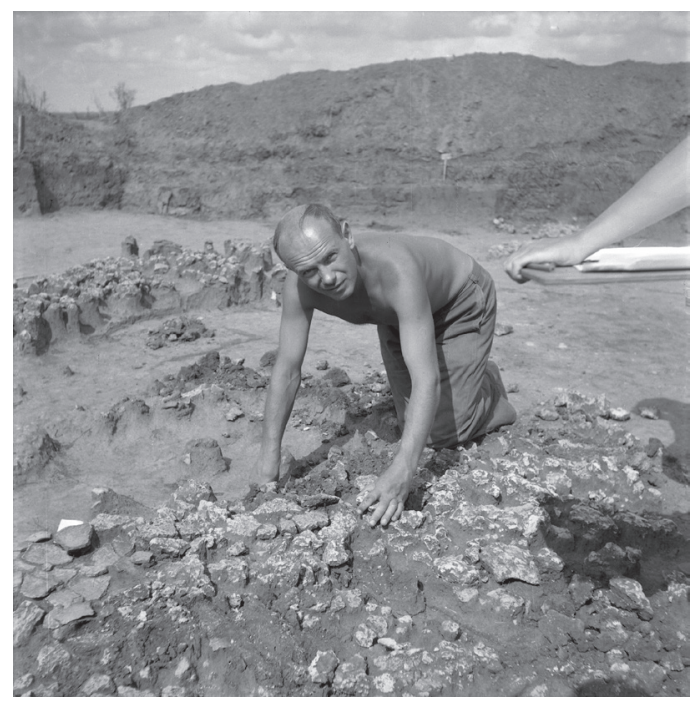

Fig. 4. Jan Kowalczyk during the excavation in Gródek on the Bug [Nadbużny], Hrubieszów district. Photo: T. Biniewski. 
PAN was prepared, while Krzemionki Opatowskie remained in the administration of the PMA. An important result of the said research was the summary (Balcer 1996) of their results by Bogdan Balcer, Cel i wyniki badan w Krzemionkach $w$ latach I969-1970 [Objectives and Results of Studies in Krzemionki in 1969-1970] that was published in the third volume of the PMA publication series: Studia nad Gospodarka Surowcami Krzemiennymi w Pradziejach [Studies on the Economy of Flint Raw Materials in Prehistory]. Bogdan Balcer was one of the eminent specialists in the field of Neolithic flint working, and this synthesis underlining the role of Jan Kowalczyk as the field director of the research of mine No. 5, is a proper expression of respect and responsibility for the work that had been started but for many reasons not finished.

JAN KOWALCZYK AT THE INSTITUTE OF THE HISTORY OF MATERIAL CULTURE OF THE POLISH ACADEMY OF SCIENCES

The "Warsaw" story of Jan Kowalczyk is also the time of his work at the Institute of the History of Material Culture of the Polish Academy of Sciences (IHKM PAN; since 1992 the Institute of Archaeology and Ethnology of the Polish Academy of Sciences) where he moved in 1972 . This was - especially in comparison with others a relatively short period, covering only slightly over six years (October I, I972 November 3I, 1978), ended with his early retirement and return to Lublin.

Based on the resolution of the Scientific Council and the decision of the Scientific Secretary of the Polish Academy of Sciences, Professor Jan Kaczmarek, Jan Kowalczyk was employed at IHKM PAN as an independent scientific worker, carrying out research tasks related to the problem: Research on ethnogenesis, development and culture of ancient societies, especially the Slavic ones, topic I.3.3: Formation of new economic and social relations in the Neolithic and the Bronze Age. Throughout his work at the Institute, he was also the Head of the Stone Age Department, gathering a large group of researchers dealing with the diverse issues of Palaeolithic, Mesolithic and Neolithic periods. Among them were: Romuald Schild, Maria Chmielewska, Maria Marczak, Halina Królik, Jadwiga Mościbrodzka, Elżbieta Sachse-Kozłowska, Hanna Więckowska, Jan Trzeciakowski, Bogdan Balcer, Danuta Rauhut, Ludmiła Graba-Łęcka-Paderewska, Leszek Gajewski, Jacek Lech and Zygmunt Krzak.

In addition to coordinating the research work of the team, Jan Kowalczyk also took an active part in the scientific life of the Institute, participating in national and international conferences and symposia. In 1975, after the death of Professor Zofia Podkowińska, and in accordance with her testamentary bequest and will, he supervised the transfer of her archaeological book collection to the Department he managed.

Jan Kowalczyk also held other responsible functions: he was a member of the Scientific Council of the IHKM PAN, in which he chaired the Section of Planning and 
I8 Jan Gurba, Hanna Kowalewska-Marszatek, Barbara Satacińska, Stawomir Sataciński

Evaluation of Scientific Research, he was the Chairman of the Committee of Evaluation and Reception of the Institute's Research Works (until August 1976).

An important part of his scientific activity during this period was editorial work. It was a difficult time in that the monumental five-volume synthesis Prahistoria Ziem Polskich [Prehistory of the Polish Lands] was being prepared, edited since 1975 by Witold Hensel. Jan Kowalczyk became a co-editor, along with Aleksander Gardawski (and after the latter's death in 1974 - an editor) of volume III: Wczesna epoka brazu [Early Bronze Age] (1978), which obtained the team award of the Scientific Secretary of the Polish Academy of Sciences. In 1976, after the death of Professor Z. Rajewski, he was also the editor-in-chief of the periodical Archeologia Polski, a position that he held until the end of 1978. In that time, three volumes appeared: vol. XXI/2 (1976), vol. XXII/I-2 (1977) and vol. XXIII/I-2 (1978).

Administrative and especially editorial duties affected the number of individual publications of Jan Kowalczyk. The latter mainly included synthetic thematic entries in the collective work Encyklopedia sztuki starożytnej: Europa, Azja, Afryka, Ameryka [Encyclopedia of ancient art: Europe, Asia, Africa, America], published in 1974: "Neolithic", "Globular Amphora culture", "Pit-and-Comb Pottery culture", "Corded Ware culture", "Danubian cultures", "Bell Beaker culture", "Tripolye culture". This publication, preceded by the introduction of Kazimierz Michałowski, contains 1500 entries and rich, colourful illustrative material, and is a joint work of Polish researchers: archaeologists and art historians. It is a valuable contribution to the achievements of the sciences researching the past, different from previous syntheses, among other things, in taking into account - beside the Middle Eastern civilizations and those of the Mediterranean basin - also contemporary cultures from other parts of Europe.

Jan Kowalczyk was also the author of the Introduction to, and at the same time the editor of, an important monographic publication Cmentarzysko kultury amfor kulistych $w$ Ztotej Sandomierskiej [Cemetery of the Globular Amphora Culture in Ztota Sandomierska] (1977) - this was a return to his earliest research interest in the funerary rituals of Neolithic societies, especially those related to the GAC.

In spite of many absorbing and time-consuming activities at the Institute, Jan Kowalczyk did not resign from didactic work. In the 1976 academic year, he resumed lectures at the UMCS in Lublin and continued this activity until the end of his stay in Warsaw. In 1978 he also undertook the function of the $\mathrm{PhD}$ thesis supervisor of MA Witold Gumiński, handing him over materials from his own excavation research in Gródek. The dissertation, prepared in framework of the Doctoral Study at IHKM PAN and defended in 1983, was published in the series Polskie Badania Archeologiczne (Gumiński 1989).

In the general opinion of his collaborators, Jan Kowalczyk was a good man, and his attitude to people was always characterized by [...] great kindness, and he always eager to give helpful advice for the younger employees of the Department (from the opinion of Prof. R. Schild, 6/7/1978). This was reflected both in the jubilee texts prepared in 
his lifetime (Balcer 1998) as well in later memories (Zakościelna and Gurba 2007; 2007a; Balcer 2015).

The merits of Jan Kowalczyk were also appreciated by his superiors, as evidenced by a congratulatory letter from the Scientific Secretary of the Polish Academy of Sciences, Prof. Jan Kaczmarek, from 19.07.1975, and the Golden Cross of Merit granted him by the resolution of the Council of State of January 5, 1979 for outstanding merits in professional work and social activity (resolution No. O-2).

Jan Kowalczyk was undoubtedly an outstanding researcher. In the archaeological environment contemporary to his activity, in addition to the naturally debatable substantive issues, he was perceived as a person with great personal culture, bearing kindness towards collaborators, both colleagues in the field of science, and technical departments of both institutions, with which he was associated.

The research inquisitiveness of Jan Kowalczyk and his critical approach towards existing views are known. In question of Neolithic research, he presented a holistic, visionary approach. He formulated long-term research programmes resulting from the current scientific needs of his time (e.g. research on chronology), but which were adapted to the practical possibilities of their implementation. One of such programmes concerned research of the Sandomierz Upland, another one - of north-eastern Poland. The effect of the first one was, among other things, the excavations on several important Neolithic sites carried out under his inspiration: on the settlements of the FBC in Kamien Łukawski and in Zawichost at the site "Pieczyska - Zbrza Wielka", both in the Sandomierz district, and in the area of the flint mine in Świeciechów, Kraśnik district. They were run by young associates of "Mister Docent" from the Neolithic Department of the PMA: Dr Elżbieta Kempisty and Bogdan Balcer, realizing - albeit on a small scale - the idea of teamwork at its best.

One should also underline the didactic passion of Jan Kowalczyk, visible both in his almost constant cooperation with the university - his parent UMCS - but also in the approach to young collaborators, whether at work in the PMA or later - at IHKM PAN. He was also characterised by his kindness and empathy in relation to others. Bogdan Balcer regarded him as his teacher and master. He gave this expression many times, emphasizing that Jan Kowalczyk conducted his work from student to docent (Balcer 20I5: 134). He always emphasized Jan Kowalczyk's careful supervision of his own scientific work, field activities and his kindness in personal matters. He stated that in the profession, he owed him as much as he did to his parents in life.

The assessment of Jan Kowalczyk as an investigator of the highest rank and at the same time a man friendly to the academic environment in which he worked, is underlined by respectful and friendship jubilee memorial writings published in the Lublin and Warsaw centres. 
20 Jan Gurba, Hanna Kowalewska-Marszatek, Barbara Satacińska, Stawomir Sataciński

\section{REFERENCES}

Abramowicz, A. 20Io. Koral pamięci, II. Łódź.

Balcer, B. 1996. Cel i wyniki badań w Krzemionkach w latach 1969-1970. In W. Brzeziński, W. Borkowski and W. Migal (eds), Z badań nad wykorzystaniem krzemienia pasiastego, 167-193. Warszawa. Studia nad Gospodarką Surowcami Krzemiennymi w Pradziejach 3.

Balcer, B. 1998. Jubileusz osiemdziesięciolecia doc. dr hab. Jana Kowalczyka. Archeologia Polski 43(I-2): II-III.

Balcer, B. 20I5. Sześćdziesiąt lat z archeologią w życiu cyklisty. Łódź.

Białasiewicz, W. and Gzella, A. L. 1994. Bronili Lublina, wrzesień 1939. Lublin.

Bieleń, Z. 2005. Powojenne losy Biblioteki Publicznej im. Hieronima Łopacińskiego (do połączenia z Miejską Biblioteka Publiczną w 1948 r.). Bibliotekarz Lubelski 48: 7-26.

Gumiński, W. 1989. Gródek Nadbużny. Osada kultury pucharów lejkowatych. Wrocław-Warszawa-KrakówGdańsk-Łódź. Polskie Badania Archeologiczne 28.

Hensel, W. 1958. W sprawach terminologicznych. Wiadomości Archeologiczne 25: 175-179.

Kempisty, E. and Gurba, J. 1971. Z zagadnień początków neolitu polskiego. Wiadomości Archeologiczne 36(I): $38-43$.

Kmieciński, J. (ed) 1989. Pradzieje ziem polskich. T. I. Od paleolitu do środkowego okresu lateńskiego. Warszawa-Łódź.

Kowalczyk, J. 1953. Dwa groby kultury amfor kulistych z Lasu Stockiego i Stoku, pow. Puławy. Sprawozdania PMA V(I-2): 38-47.

Kowalczyk, J. 1956. Osada kultury pucharów lejkowatych w miejscowości Gródek Nadbużny, pow. Hrubieszów w świetle badań 1954 r. Wiadomości Archeologiczne 23: 23-48.

Kowalczyk, J. I957a. Badania osady kultury pucharów lejkowatych w Gródku Nadbużnym, pow. Hrubieszów, przeprowadzone w 1955 r. Wiadomości Archeologiczne 24(I-2): 37-52.

Kowalczyk, J. 1957b. Osada i cmentarzysko kultury pucharów lejkowatych w miejscowości Klementowice, powiat Puławy. Materiaty Starożytne II: 175-206.

Kowalczyk, J. I957c. Sprawozdanie z badań osady kultury pucharów lejkowatych w Gródku Nadbużnym, pow. Hrubieszów, w 1956 r. Wiadomości Archeologiczne 24(4): 300-306.

Kowalczyk, J. 1959a. Prace badawcze w 1957 r. osady kultury pucharów lejkowatych w Gródku Nadbużnym, pow. Hrubieszów. Wiadomości Archeologiczne 25/1958(4): 314-32I.

Kowalczyk, J. I959b. Zagadnienie kultury mierzanowickiej zwanej także tomaszowską. Wiadomości Archeologiczne 26(I-2): I-8.

Kowalczyk, J. 196r. Die Trichterbecherkultur und Tripolje. In L'Europe à la fin de l'âge de la pierre, Actes du Symposium consacré aux problèmes du Néolithique européen. Prague, Liblice, Brno, 5-I2 octobre 1959, 20I-204. Praha.

Kowalczyk, J. 1962a. Nim koło zaczęło służyć człowiekowi. Mówiq wieki 5(I): 45-47.

Kowalczyk, J. 1962b. A settlement of the Funnel Beaker culture at Gródek Nadbużny in the Hrubieszów district. Archaeologia Polona 4: III-I2O.

Kowalczyk, J. 1962c. "Sondaż terenowy” w badaniach archeologicznych. Wiadomości Archeologiczne 28(4): $301-307$.

Kowalczyk, J. 1962d. Uwagi o problematyce i postulatach badawczych neolitu polskiego. Wiadomości Archeologiczne 27(3): 27I-282.

Kowalczyk, J. 1962e. Zagadnienie grobów zbiorowych w neolicie Polski. Wiadomości Archeologiczne 28(I): I-I2.

Kowalczyk, J. 1963a. Niektóre problemy polskiego neolitu w świetle nowszych badań. Prace i Materiaty Muzeum Archeologicznego i Etnograficznego w Eodzi. Seria Archeologiczna 10: 65-75. 
Kowalczyk, J. 1963b. Terminologiczne konsekwencje. Wiadomości Archeologiczne 29(I): I-8.

Kowalczyk, J. 1964a. Lud amfor kulistych, cz. I. Z otchtani wieków 30(3): 146-I55.

Kowalczyk, J. I964b. Lud amfor kulistych, cz. II. Z otchtani wieków 30(4): 217-225.

Kowalczyk, J. 1964c. Uwagi o organizowaniu wystaw. Wiadomości Archeologiczne 30(I-2): I17-I20.

Kowalczyk, J. 1968a. Dwa zespoły neolityczne datowane radiowęglem. Wiadomości Archeologiczne 33(3-4): 368-376.

Kowalczyk, J. 1968b. Zagadnienie przeobrażeń kulturowych w neolicie. Acta Archaeologica Lodziensia I7: $77-85$.

Kowalczyk, J. 1968c. Z zagadnień kultury ceramiki sznurowej. In K. Jażdżewski (ed.), Liber Iosepho Kostrzewski octogenario a veneratoribus dicatus, II7-I23. Wrocław.

Kowalczyk, J. I969a. Neolit przedceramiczny na ziemiach polskich? Z otchtani wieków 35(I): 9-II.

Kowalczyk, J. 1969b. Początki neolitu na ziemiach polskich. Wiadomości Archeologiczne 34(I): 3-69.

Kowalczyk, J. 1970. The Funnel Beaker Culture. In T. Wiślański (ed.), The Neolithic in Poland, I44-177. Wrocław-Warszawa-Kraków.

Kowalczyk, J. 1971a. Główne problemy polskiego neolitu. Sprawozdania Archeologiczne 23: 405-409.

Kowalczyk, J. 197ıb. Zmierzch epoki kamienia. Wrocław-Warszawa-Kraków-Gdańsk. Popularnonaukowa Biblioteka Archeologiczna i7.

Kowalczyk, J. 1972. W związku z dyskusją nad początkami neolitu. Wiadomości Archeologiczne 36/1971(3): 243-252.

Kozłowski, J. K. I97I. W sprawie początków neolitu na ziemiach polskich. Wiadomości Archeologiczne 36(I): 44-50.

Libera, J. and Gurba, J. 2003. Rozmowa z doc. Janem Gurbą, byłym kierownikiem Katedry Archeologii UMCS w latach 1974-I994. Z otchtani wieków 58: 6-II.

Hensel, W. (ed.) 1975. Prahistoria ziem polskich. T. I. Paleolit i mezolit (eds vol. W. Chmielewski and W. Hensel). Wrocław-Warszawa-Kraków-Gdańsk.

Hensel, W. (ed.) 1978. Prahistoria ziem polskich. T. III. Wczesna epoka brązu (eds vol. A. Gardawski and J. Kowalczyk). Wrocław-Warszawa-Kraków-Gdańsk.

Hensel, W. (ed.) 1979. Prahistoria ziem polskich. T. II. Neolit (eds vol. W. Hensel and T. Wiślański). Wrocław-Warszawa-Kraków-Gdańsk.

Rozwałka, A. 2003. 85-lecie urodzin Nestora lubelskiej archeologii. Wiadomości Uniwersyteckie UMCS I3(I0): I8-I9.

Zakościelna, A. 1999. Jubileusz Nestora lubelskiej archeologii. Archeologia Polski Środkowowschodniej 4: 272-273.

Zakościelna, A. and Gurba, J. 2007. Doc. dr hab. Jan Kowalczyk (1918-2007). Archeologia Polski Środkowowschodniej 9: 384-387. 
